\title{
Ribosome assembly in three strains of Escherichia coli with mutations in the $\operatorname{rpmB}, G$ operon
}

\author{
Struan H. Coleman, Bruce A. Maguire and Donald G. WilD* \\ Microbiology Unit, Biochemistry Department, University of Oxford, South Parks Road, Oxford OX13QU, UK
}

(Received 9 September 1992; revised 3 December 1992; accepted 18 December 1992)

\begin{abstract}
The rpmB,G operon of Escherichia coli codes for the synthesis of ribosomal proteins L28 and L33. In one mutant strain (TP28), these two proteins are made at about half their normal rates, ribosome assembly is greatly perturbed and precursor particles accumulate. The mutation in strain TP28 is in a Shine-Dalgarno sequence in the leader region of the rpmB,G messenger RNA. Another mutant, strain AM108, makes neither protein because it has the mobile element ISI inserted into the rpmB coding sequence. Surprisingly, ribosome assembly in this strain is virtually normal with respect to growth rate. Strain AM90, which fails to make protein L33, has the element IS3 inserted into rpmG and also shows no major defects in ribosome assembly.
\end{abstract}

\section{Introduction}

Ribosome assembly in Escherichia coli involves coordinated synthesis of three ribosomal RNAs and over fifty ribosomal proteins. Rates of synthesis of the ribosomal RNAs adjust to the medium in which organisms are growing; in extreme circumstances, synthesis is shut off if organisms are starved of an amino acid. A number of control mechanisms is involved whose apparent redundancy implies that regulation is still possible if one is inactivated (Ross et al., 1990). There is transcriptional control of ribosomal protein synthesis but the final adjustment of rates is usually by regulation of translation of the ribosomal protein operons (Lindahl \& Zengel, 1986). Often, a protein of an operon that binds directly to ribosomal RNA during ribosome assembly also binds, more weakly, to the leader region of its messenger RNA and, if in excess, inhibits translation of all the proteins of the operon.

A consequence of co-ordinated synthesis is that only $2-5 \%$ of the ribosomal RNA of exponentially-growing cells is in ribosomes in course of synthesis (Lindahl, 1975). The pools of most ribosomal proteins unassociated with RNA are also small (Ulbrich \& Nierhaus, 1975). In a number of circumstances, though, ribosome assembly can be disturbed so that precursor particles accumulate. Organisms treated with low concentrations of protein-synthesis inhibitors accumulate ribosome

\footnotetext{
*Author for correspondence. Tel. (0865) 275307; fax (0865) 275297.
}

Abbreviation: m.g.t., mean generation time. precursors akin to those detected in exponentiallygrowing cells. Some conditional mutants accumulate precursor particles at restrictive temperatures. Assembly can be defective without conferring a cold- or temperature-sensitive phenotype; for example, some strains that have reverted from erythromycin-dependence show unbalanced synthesis of RNA and protein and accumulate ribosome precursors during slow exponential growth (Wild, 1988).

E. coli strain TP28, another example of an organism with defective ribosome assembly, accumulates unusual ' $47 \mathrm{~S}$ ' particles during exponential growth at $37^{\circ} \mathrm{C}$. The assembly mutation was shown to be near, and probably within, the $\operatorname{rpmB}, G$ operon that codes for ribosomal proteins L28 and L33; both proteins are made at about half their normal rates (Butler \& Wild, 1984, 1985). The mutation has other consequences. The $47 \mathrm{~S}$ particles lack proteins L28 and L33 and have substoicheiometric amounts of at least three others, L16, L25 and L27. Synthesis takes place as though the particles, rather than 50S subunits, are the end products (Butler et al., 1979, 1980). Thus, at $20^{\circ} \mathrm{C}$, there are three sequential precursors to $47 \mathrm{~S}$ particles analogous to the three precursors to the 50S subunits of the parent strain. The 47S particles subsequently acquire the proteins they lack to become the 50S subunits of $70 \mathrm{~S}$ ribosomes. The latter now have a complete set of ribosomal proteins but function poorly in protein synthesis (Sims \& Wild, 1976).

The present work shows that the assembly mutation in strain TP28 is a single base change in the putative Shine-Dalgarno sequence of a ribosome-binding site in the leader region of the mRNA for proteins L28 and 
L33. In addition, the work examines two other strains, AM90 and AM108, whose parent is strain AM, an erythromycin-dependent derivative of $E$. coli strain A19 (Dabbs, 1979). Spontaneous revertants of strain AM to erythromycin independence are often organisms in which failure to make one or more ribosomal proteins suppresses the dependency. Ribosomes from strain AM90 lack ribosomal protein L33 while those from strain AM108 have neither L28 nor L33; cross-reacting material is also absent (Dabbs et al., 1983). Our expectation was that these strains, particularly AM108, would have similar (or greater) defects in ribosome assembly than strain TP28. However, this is not the case. Possible reasons for this are discussed. The mutations in strains AM90 and AM108 are identified.

\section{Methods}

Bacteria and media. The strains of $E$. coli used were (i) 15 thy pro (15TP) and the mutant 15-28 (TP28) derived from it; (ii) two transductants of the K12 strain RE74; in RE74-807, pyrE $E^{+}$and the linked ribosome mutation have been transferred from TP28, while in RE74-803, pyr $E^{+}$, but not the ribosome mutation, is present (Butler \& Wild, 1985); (iii) strain A19 (Gesteland, 1966), the erythromycindependent strain, AM, derived from A19, and two revertants to erythromycin-independence, strains AM90 and AM108 (Dabbs, 1979); (iv) revertants to erythromycin-independence (strains R1, R5, R10 and R15) of the erythromycin-dependent strain 103 (Wild, 1988).

Bacteria were grown in liquid media with shaking at $37^{\circ} \mathrm{C}$. The media were as follows. (i) DP-broth, which contained, per litre, $10 \mathrm{~g}$ tryptone, $10 \mathrm{~g}$ yeast extract, $5 \mathrm{~g}$ glucose, $3 \mathrm{~g} \mathrm{KH}_{2} \mathrm{PO}_{4}, 7 \mathrm{~g} \mathrm{~K}_{2} \mathrm{HPO}_{4}$, $500 \mathrm{mg}$ trisodium citrate and $200 \mathrm{mg} \mathrm{MgSO} \cdot 7 \mathrm{H}_{2} \mathrm{O}$. (ii) Tris-buffered amino acid (TAA) medium; this contained, per litre of $0.1 \mathrm{M}$-Tris/ $\mathrm{HCl} \mathrm{pH} \mathrm{7.4,} 2 \mathrm{~g}$ glucose, $2 \mathrm{~g} \mathrm{KCl}, 2 \mathrm{~g} \mathrm{NH}_{4} \mathrm{Cl}, 500 \mathrm{mg} \mathrm{MgCl} .6 \mathrm{H}_{2} \mathrm{O}$, $178 \mathrm{mg} \mathrm{Na}{ }_{2} \mathrm{HPO}_{4}, 50 \mathrm{mg} \mathrm{Na} \mathrm{SO}_{4}, 2 \mathrm{mg} \mathrm{Fe}\left(\mathrm{NH}_{4}\right)_{2}\left(\mathrm{SO}_{4}\right)_{2} .6 \mathrm{H}_{2} \mathrm{O}, 8 \mathrm{mg}$ uracil and $40 \mathrm{mg}$ each of $19 \mathrm{~L}$-amino acids (the set of 20 without lysine). TAA medium (with lysine added as below) was used when subsequent analysis was of ribosome assembly or of ribosomal proteins. (iii) Lbroth, which contained, per litre, $10 \mathrm{~g}$ tryptone, $5 \mathrm{~g}$ yeast extract, $5 \mathrm{~g} \mathrm{NaCl}, 1 \mathrm{~g}$ glucose and $30 \mathrm{mg} \mathrm{L}$-cysteine. $\mathrm{HCl}$, and supplemented as appropriate with $60 \mathrm{mg}$ ampicillin and/or $50 \mathrm{mg}$ tetracycline. This medium was used for maintenance and selection of plasmids and when DNA was subsequently isolated.

Detection of ribosomes and ribosome precursor particles. $\left[{ }^{3} \mathrm{H}\right] \mathrm{Uracil}$ and/or $\left[{ }^{14} \mathrm{C}\right]$ uracil were used to label RNA during growth in TAA medium containing $40 \mu \mathrm{g}$ lysine $\mathrm{ml}^{-1}$. Harvested organisms were washed in $10 \mathrm{~mm}$-Tris $/ \mathrm{HCl}, \mathrm{pH} \mathrm{7 \cdot 4}$, containing $10 \mathrm{~mm}$-magnesium acetate (THM buffer) and resuspended in THMKSp buffer (THM buffer plus $100 \mathrm{~mm}-\mathrm{KCl}$ and $1 \mathrm{~mm}$-spermidine. $\mathrm{HCl}$ ). Extracts were made and density-gradient centrifuging done as previously (Wild, 1988).

Synthesis of ribosomal proteins by strain AM108. For pulse-chase experiments, carrier-free $\left[{ }^{3} \mathrm{H}\right]$ lysine $\left(84 \mathrm{Ci} \mathrm{mmol}^{-1} ; 7.5 \mu \mathrm{Ci} \mathrm{ml}^{-1}\right)$ was added at $\mathrm{OD}_{450} 0.3$ to cultures growing exponentially in TAA medium without lysine, followed, after $2 \mathrm{~min}$, by non-radioactive lysine (final concn $\left.1 \mathrm{mg} \mathrm{ml}^{-1}\right)$. Samples $(10 \mathrm{ml})$ taken at $4 \mathrm{~min}$ and later were poured onto crushed ice and $10 \mathrm{ml}$ of a reference culture (strain AM108 labelled for two generations with $\left[{ }^{14} \mathrm{C}\right]$ lysine $[0.2 \mu \mathrm{Ci}(7.4 \mathrm{kBq})$ and $\left.5 \mu \mathrm{g} \mathrm{ml}^{-1}\right]$ ) added. Harvested bacteria were washed, resuspended in buffer, broken in a French pressure cell and ribosomal proteins extracted with acetic acid; the methods, the subsequent electrophoresis in the 'standard' buffer system and the assay of radioactivity in protein spots were as previously (Butler \& Wild, 1984). The ratios of radioactivities in protein spots were normalized (Dennis, 1974): for protein $i$, the ratio $\mathrm{A}_{\mathrm{i}}=\left({ }^{3} \mathrm{H} /{ }^{14} \mathrm{C}\right.$ in protein $\left.\mathrm{i}\right) /\left({ }^{3} \mathrm{H} /{ }^{14} \mathrm{C}\right.$ in total ribosomal protein).

DNA manipulations. Unless noted below, standard procedures were used (Sambrook et al., 1989). Chromosomal DNA was isolated from bacteria grown in L-broth. The polymerase chain reaction (PCR) was used to amplify DNA of the $\operatorname{rpmB}, G$ operon. The primers were made in the Dyson Perrins Laboratory, Oxford. Primer 1 was AATTTGAATTCACCCGCTATGCGCGATCCTT, with five flanking nucleotides at the $5^{\prime}$ end, an EcoRI restriction site (underlined) and 20 nucleotides complementary to the non-coding strand at the $5^{\prime}$ end of the published sequence (Lee et al., 1981; their numbering is used throughout this paper). Primer 2 was TAGTAAAGCTTCGGGTAATTCAGGCATAGCA, with a flanking zone, a HindIII site and 20 nucleotides complementary to the coding strand at the $3^{\prime}$ end of the sequence. The PCR was run for 30 cycles with a Perkin-Elmer heating block and used $0.1 \mu \mathrm{g}$ chromosomal DNA and $0.01 \mu \mathrm{g}$ of each primer per reaction mixture $(100 \mu \mathrm{l})$. The products were run on a $1 \%(\mathrm{w} / \mathrm{v})$ agarose gel and a designated DNA band collected by electroelution. The DNA, recovered by ethanol precipitation, was ligated into plasmid pTZ18R (from Dr K. G. H. Dyke, Microbiology Unit, Oxford University) after digestion of both fragment and vector with $E c o$ RI and HindIII. The products were transformed into E. coli strain JM109. Sequencing was with the Sequenase $2.0 \mathrm{kit}$ and the 'Sequencing' and 'Reverse Sequencing' primers (from Boehringer-Mannheim); two other 18-nucleotide primers that corresponded to sequences (or their complement) within the operon were used to help sequence the operons from strains AM90 and AM108.

lac fusions. These were made from PCR-generated mRNA leader sequences. For the leader from strain 15TP, the source of DNA was the rpmB, $G$ operon cloned into pTZ18R; the primers were $(a)$ the same as the sequence from nucleotides -216 to -199 , and $(b)$ the complement of nucleotides -14 to +3 . The product therefore included the promoter for the $r p m B, G$ operon, the Shine-Dalgarno sequence and the first three translated nucleotides (ATG). For strain TP28, the second primer was one nucleotide different so as to complement the altered Shine-Dalgarno sequence. The products were blunt-end ligated into plasmid pUI553A (kindly given by Dr S. Kaplan, Department of Microbiology, University of Texas) cut with StuI. Because StuI does not digest DNA isolated from $d_{a m^{+}} d_{c m}{ }^{+}$strains of $E$. coli, pUI533A had been transformed into the dam dcm strain GM48 (from Dr P. Nurse, Microbiology Unit, Oxford University) and purified. lac fusions were screened on L-agar plates containing tetracycline and X-Gal, purified, and plasmid DNA transformed into strain JM109. Constructs were checked by sequencing. $\beta$-Galactosidase assays on organisms grown in Davis-Mingioli medium containing tetracycline were done following Miller (1972).

\section{Results}

Assembly of ribosomes

Strains A19, AM90, AM108, 15TP and TP28 were grown in DP-broth to $\mathrm{OD}_{450} 0.5$. The dependent strain, $\mathrm{AM}$, was grown similarly but with $100 \mu \mathrm{g}$ erythromycin $\mathrm{ml}^{-1}$. Extracts were made and centrifuged through sucrose gradients (Fig. $1 a-f$ ). The two parent strains, A19 and 15TP, have normal profiles, with native $30 \mathrm{~S}$ and $50 \mathrm{~S}$ subunits present in small quantities relative to $70 \mathrm{~S}$ 


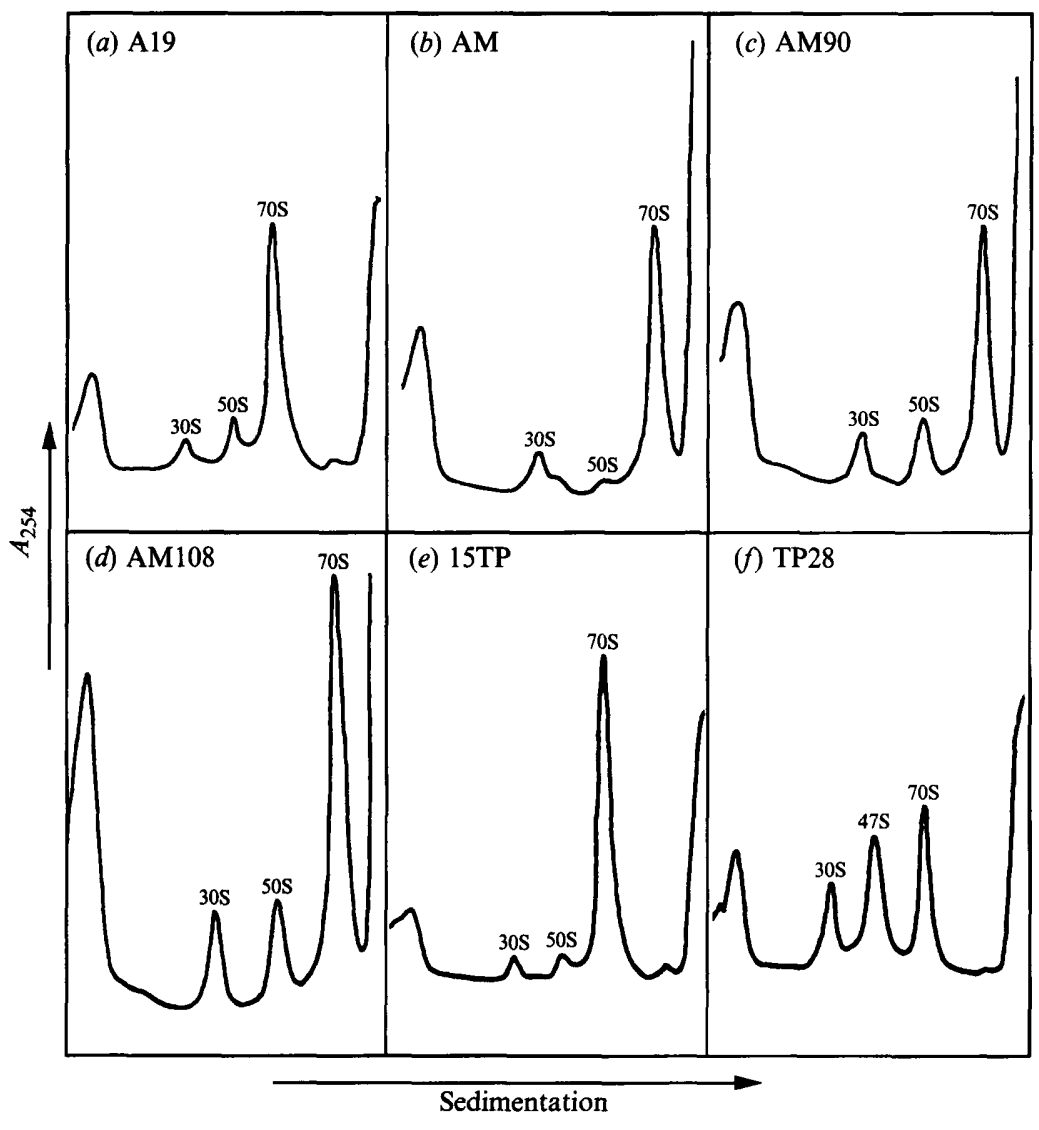

Fig. 1. Sedimentation profiles of ribosomal particles from wild-type and mutant strains after sucrose-density gradient centrifugation. Extracts were made from $(a)$ strain A19, $(b)$ strain AM (after growth with $100 \mu \mathrm{g}$ erythromycin $\left.\mathrm{ml}^{-1}\right),(c)$ strain AM90, $(d)$ strain AM108, $(e)$ strain 15TP and $(f)$ strain TP28.
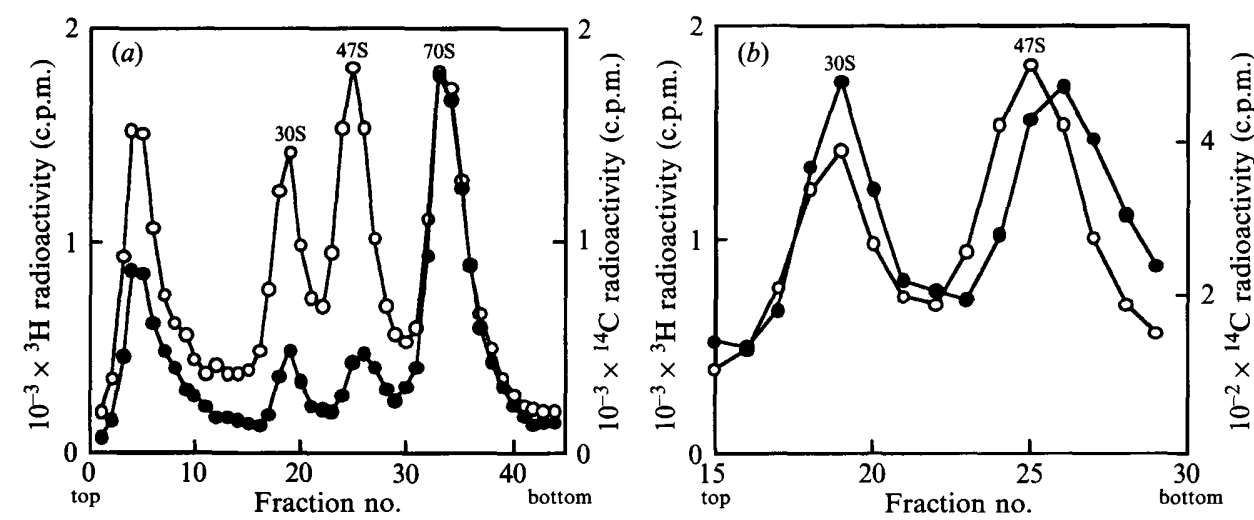

Fig. 2. Sedimentation profiles of mixed extracts from strains TP28 and AM108. Strain TP28 was grown from $\mathrm{OD}_{450}$ to 0.05 to 0.50 in DP-broth containing [ $\left.{ }^{3} \mathrm{H}\right]$ uracil $\left[1 \mu \mathrm{Ci}(37 \mathrm{kBq}) \mathrm{ml}^{-1}\right]$; strain AM 108 was grown similarly but with $\left[{ }^{14} \mathrm{C}\right] \mathrm{uracil}\left[0 \cdot 1 \mu \mathrm{Ci}(3 \cdot 7 \mathrm{kBq}) \mathrm{ml}^{-1}\right]$. Extracts made with a French pressure cell were mixed and centrifuged. Panel $(a)$ shows the complete profile from the gradient; in $(b)$, a portion of $(a)$ is redrawn to show more clearly the different sedimentation properties of $47 \mathrm{~S}$ particles from strain $\mathrm{TP} 28$. $\mathrm{O},{ }^{3} \mathrm{H}$ radioactivity;,${ }^{14} \mathrm{C}$ radioactivity.

ribosomes. The profile from strain TP28 shows, as previously reported (Butler \& Wild, 1984), three ribonucleoprotein components in similar amounts. The $30 \mathrm{~S}$ material is a mixture of $30 \mathrm{~S}$ ribosomal subunits and a precursor to them (Markey \& Wild, 1975); the '47S' particles are abnormal precursors to 50S ribosomal subunits that sediment more slowly than the subunits.
The profile of strain AM (Fig. $1 b$ ) shows fewer 50S ribosomal subunits than its parent, strain $\mathrm{A} 19$, while the $30 \mathrm{~S}$ subunits have a shoulder of faster-sedimenting material. These changes are a consequence of growth with erythromycin, which, like other antibiotics that inhibit protein synthesis, uncouples RNA and protein synthesis and so alters ribosome assembly (B. A. 

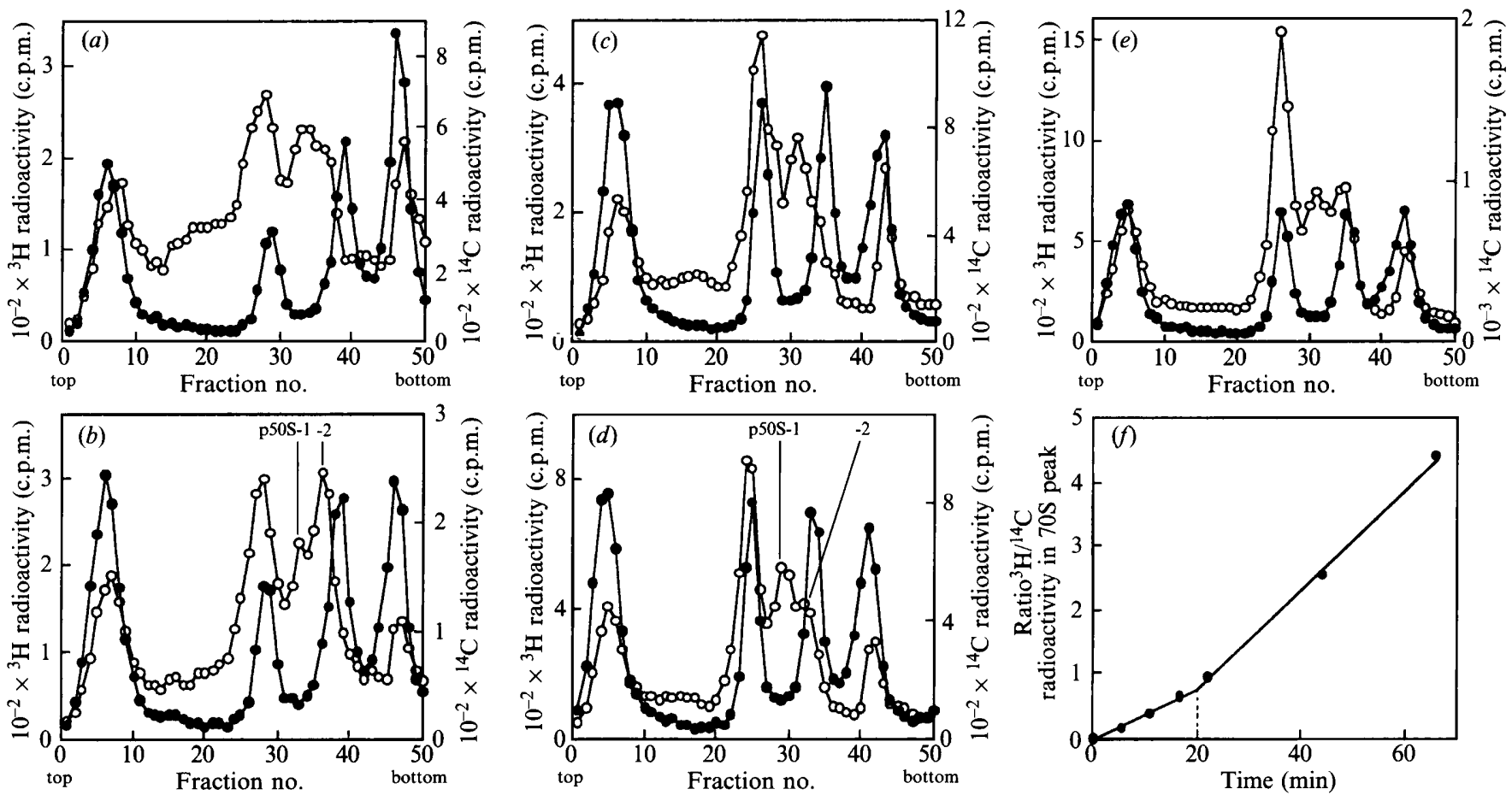

Fig. 3. Ribosome assembly in strains A19 and AM108. (a,b) Strain A19 was grown (m.g.t. 36 min) from OD 450 0.12 to 0.5 in TAA medium containing $\left[{ }^{14} \mathrm{C}\right]$ uracil $\left[8 \mu \mathrm{g}\right.$ and $\left.0.03 \mu \mathrm{Ci}(1.1 \mathrm{kBq}) \mathrm{ml}^{-1}\right]$. Then $\left[{ }^{3} \mathrm{H}\right]$ uracil $\left[7.5 \mu \mathrm{Ci}(278 \mathrm{kBq}) \mathrm{ml}^{-1}\right]$ was added. Samples $(10 \mathrm{ml})$ were poured onto $10 \mathrm{~g}$ crushed ice at $-20^{\circ} \mathrm{C}$. Harvested cells were lysed and portions of extracts centrifuged through sucrose gradients. Times of ${ }^{3} \mathrm{H}$-labelling were $(a) 30 \mathrm{~s},(b) 1 \mathrm{~min}$. Panels $(c)-(e)$ show a similar experiment with strain AM108 (m g.t. $\left.224 \mathrm{~min}\right)$. Labelling times were $(c) 4 \min 25 \mathrm{~s},(d) 6 \min 35 \mathrm{~s},(e) 8 \mathrm{~min} 50 \mathrm{~s}$. $O{ }^{3} \mathrm{H}$ radioactivity;,${ }^{14} \mathrm{C}$ radioactivity. Panel $(f)$ is from another experiment with strain AM 108 and shows the specific radioactivity $\left({ }^{3} \mathrm{H} /{ }^{14} \mathrm{C}\right)$ of $70 \mathrm{~S}$ ribosomes plotted against the time of labelling with $\left[{ }^{3} \mathrm{H}\right]$ uracil.

Maguire \& D. G. Wild, unpublished observations). The profile of strain AM90 shows more $30 \mathrm{~S}$ and $50 \mathrm{~S}$ material than strain A19, probably because strain AM90 grows rather slowly (m.g.t. $54 \mathrm{~min}$ ). The $30 \mathrm{~S}$ and $50 \mathrm{~S}$ material is more marked in the profile of strain AM108 (m.g.t. $172 \mathrm{~min}$; Fig. 1d). Even so, strain AM108 shows none of the gross alterations characteristic of strain TP28; the areas under the $30 \mathrm{~S}$ and $50 \mathrm{~S}$ peaks are together about $50 \%$ of that under the $70 \mathrm{~S}$ ribosomes; for strain TP28, the figure is $170 \%$.

Other comparisons were made between strains TP28 and AM108. (i) The two strains were grown in DP-broth with $\left[{ }^{3} \mathrm{H}\right]$ uracil (strain TP28) or $\left[{ }^{14} \mathrm{C}\right]$ uracil (strain AM108). Extracts were made, mixed and sedimented through the same gradient. The sedimentation profiles (Fig. 2) confirm the excess of $30 \mathrm{~S}$ and $47 \mathrm{~S}$ material in strain TP28 and show that the 47S particles of strain TP28 sediment appreciably more slowly than the 50S material of strain AM108.

(ii) Ribosome assembly by strain AM108 was examined by pulse-labelling. As a control, strain A19, grown (m.g.t. $36 \mathrm{~min}$ ) in TAA medium with $\left[{ }^{14} \mathrm{C}\right]$ uracil, was pulse-labelled with $\left[{ }^{3} \mathrm{H}\right]$ uracil. Fig. $3(a, b)$ shows sedimentation profiles of samples taken after $30 \mathrm{~s}$ and $1 \mathrm{~min}$
(1.5 and $3 \%$ of a generation). The steady-state ${ }^{14} \mathrm{C}$ profiles show tRNA, 30S and 50S subunits and 70S ribosomes; polysomes, present in extracts prepared by gentle lysis, have sedimented. The pulse label shows ribosomes in course of synthesis. At $30 \mathrm{~s}$, the p50S-1 precursor to 50S ribosomal subunits (Lindahl, 1975) is more apparent than its product, the p50S-2 precursor particle; at $1 \mathrm{~min}$, this situation is reversed. A similar experiment (Fig. $3 c, d, e$ ) with strain AM108 had labelling times (4 min $25 \mathrm{~s}, 6 \mathrm{~min} 35 \mathrm{~s}$ and $8 \mathrm{~min} 50 \mathrm{~s}$ ) equivalent to 2,3 and $4 \%$ of a generation. The earliest sample shows only a p $50 \mathrm{~S}-1$ precursor to $50 \mathrm{~S}$ ribosomal subunits; subsequently, a $50 \mathrm{~S}-2$ precursor is evident. Another experiment with strain AM108 measured the ${ }^{3} \mathrm{H}$ radioactivity from a pulse-label associated with $70 \mathrm{~S}$ ribosomes at different times; the break in the curve (Fig. $3 f$ ) is when newly-made rRNA begins to enter 70S ribosomes. For strain AM108, this 'ribosome maturation time' is about $20 \mathrm{~min}$; that for strain A19 (experiment not shown) is about $3 \mathrm{~min}$. These times are 9 and $8 \%$ of the mean generation times of the organisms. Comparable figures are also obtained with strains AM $(7 \%)$ and AM90 (10\%). This constancy is similar to that shown by a strain of $E$. coli 15 grown at different rates in various 


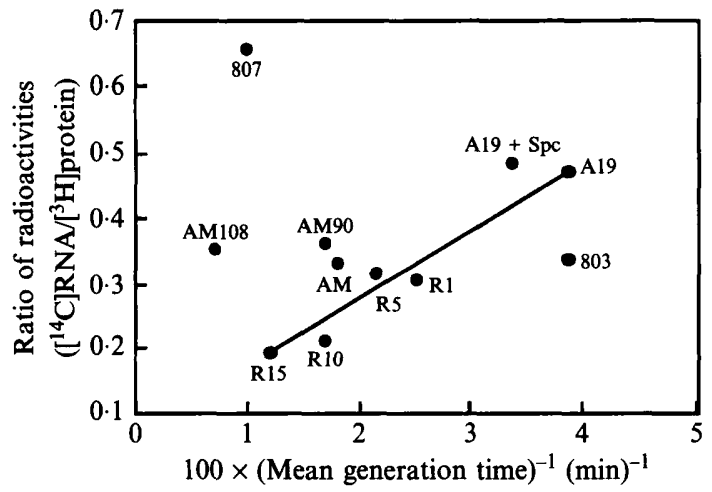

Fig. 4. RNA content of revertant strains. The strains indicated were inoculated $\left(\mathrm{OD}_{450}\right.$ approx. 0.05$)$ into portions of the same batch of DPbroth with $\left[{ }^{3} \mathrm{H}\right]$ lysine $\left[2 \mu \mathrm{Ci}(74 \mathrm{kBq}) \mathrm{ml}^{-1}\right]$ and $\left[{ }^{14} \mathrm{C}\right]$ uracil $[0.02 \mu \mathrm{Ci}$ $\left.(0.74 \mathrm{kBq}) \mathrm{ml}^{-1}\right]$ added. Strain AM and a second culture of strain A19 (indicated by ' $+\mathrm{Spc}$ ') were grown identically but with $5 \mu \mathrm{g}$ spectinomycin ml-1. At $\mathrm{OD}_{450} 0.50$, three samples $(1.0 \mathrm{ml})$ were taken from each culture for estimation of radioactivity insoluble at $0{ }^{\circ} \mathrm{C}$ in $5 \%(w / v)$ trichloroacetic acid.

media (Michaels, 1972) and is thus that expected for normal ribosome assembly.

Ribosome assembly by strain AM108 is thus very similar to that in strain A19. This contrasts sharply with strain TP28, where synthesis proceeds as though 47S particles, rather than $50 \mathrm{~S}$ ribosomes, are the end product of the pathway (Butler et al., 1979, 1980). Moreover, the ribosome maturation time is $20 \%$ of the m.g.t. in a range of growth media (R. Skelt \& D. G. Wild, unpublished observations).

\section{$R N A$ content of strains}

The RNA contents of strains A19, AM, AM90 and AM108 were compared by growing the strains in portions of the same batch of DP-broth containing $\left[{ }^{14} \mathrm{C}\right]$ uracil and $\left[{ }^{3} \mathrm{H}\right] \mathrm{lysine}$. Strain AM was grown with a low concentration $\left(5 \mu \mathrm{g} \mathrm{m}^{-1}\right)$ of spectinomycin, which supports the dependency (Maguire et al., 1989); so was a second culture of strain A19. The experiment also included (i) other strains that have reverted from erythromycin-dependence and have an RNA content normal for their growth rates (Wild, 1988) and (ii) the isogenic pair of K12 strains, RE74-803 and -807, one of which (807) has the ribosome mutation of strain TP28 (Butler \& Wild, 1985). The results (Fig. 4) confirm the high RNA content of strain RE74-807 in comparison with strain RE74-803. The RNA contents of strains AM, AM90 and AM108 are very similar to each other, but because of the slower growth of strains AM90 and 108 they lie progressively further from the base-line. However, although there may be some oversynthesis of RNA by strain AM108, this is much less marked than in strain
RE74-807 (and some other revertants to antibiotic independence; Wild, 1988).

\section{Nature of the mutations}

Chromosomal DNA was prepared from strains A19, AM, AM90, AM108, 15TP and TP28. DNA encoding the $\operatorname{rpm} B, G$ operon was amplified by PCR. The products were ligated into plasmid pTZ18R. The inserts acquired by pTZ18R from strains A19, AM, 15TP and TP28 could be excised by digestion with EcoRI and HindIII as $0.75 \mathrm{~kb}$ fragments; those from strains AM90 and AM108 were about 2.0 and $1.5 \mathrm{~kb}$ respectively. All sequences had the same set of minor differences from that of Lee $e t$ al., (1981): (i) the insertion of TA between nucleotides -88 and -87 , (ii) the absence of AC (positions -62 and -61 ), and (iii) the substitution of $\mathrm{T}$ for $\mathrm{C}$ at positions 452 and 456 . These changes are outside the sequences considered here and summarized in Fig. 5. The coding sequence of the promoter-proximal rpmB (protein L28) gene is preceded by a typical Shine-Dalgarno sequence (GGAG). There is a second potential ribosome-binding site $5^{\prime}$ to the ATG codon that initiates translation of $r p m G$ (protein L33).

The sequences from strains A19 and 15TP were the same. Strain TP28 had a single base change that altered the upstream Shine-Dalgarno sequence from GGAG to GGAA. This alteration was present in two separately amplified DNA preparations from each of two isolates of strain TP28 that had been maintained separately. Moreover, a spontaneous revertant of strain TP28 to faster growth had a single base change in the ShineDalgarno sequence back to that of strain 15TP.

The sequence from strain AM90 showed that the mobile element IS3 was inserted into $r p m G$. This accounts for the greater size of the operon. The insertion introduces an in-phase stop codon that should terminate translation of the protein after 25 (of the 54) amino acids have been polymerized. Insertion of IS3 was accompanied by the usual direct 3-nucleotide repeat in the coding sequence. In strain AM108, the element IS 1 was inserted towards the distal end of $\operatorname{rpmB}$, creating a direct 9-nucleotide repeat. Translation could give an Nterminal fragment of protein L28 with 49 of the 77 amino acids.

\section{Consequences of the genetic defects}

(a) Reduced translation from the altered Shine-Dalgarno sequence in strain TP28. lac fusions were made to compare the strengths of the Shine-Dalgarno sequences preceding rpmB in strains 15TP and TP28. The two leader sequences, amplified by PCR, were ligated into plasmid pUI533A and then transformed into strain 


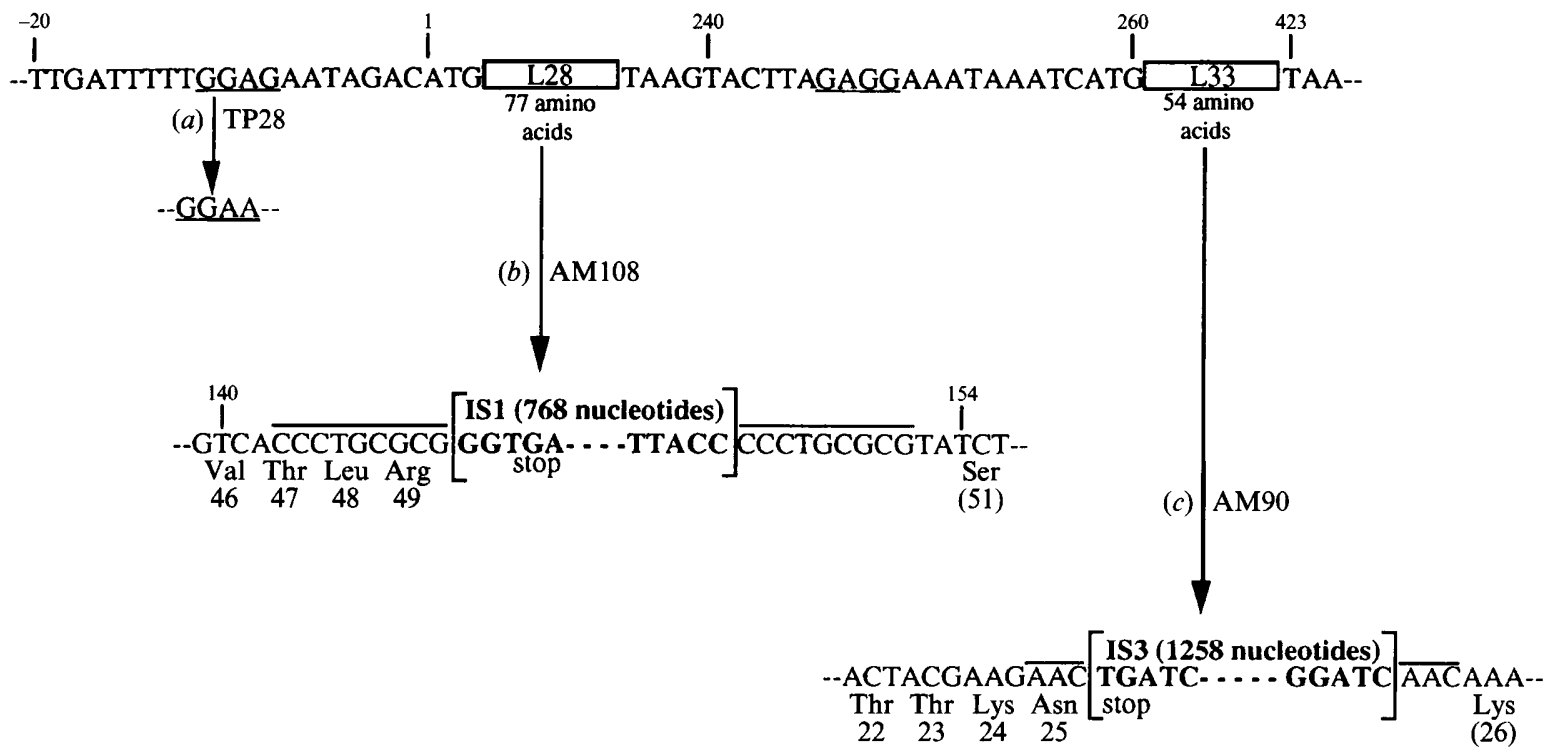

Fig. 5. Mutations in the $r p m B, G$ operon. The sequence changes in strains TP28, AM108 and AM90 are shown. Potential Shine-Dalgarno sequences are underlined. Repeats created by insertion of IS 1 and IS 3 are overlined. The central approx. 400 nucleotides of IS3 were not sequenced.

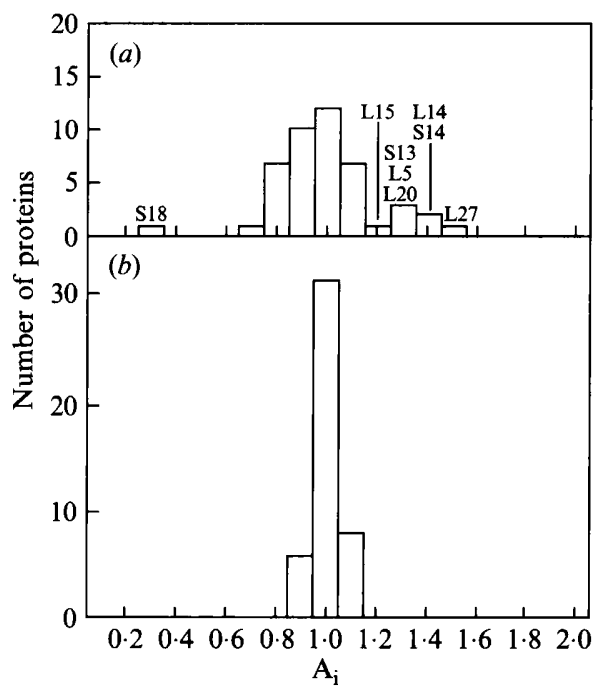

Fig. 6. Synthesis of ribosomal proteins by strain AM108. The distribution of $A_{i}$ values is shown after a 2 min pulse with $\left[{ }^{3} \mathrm{H}\right]$ lysine followed by a chase of $(a) 2 \mathrm{~min}$ and $(b) 100 \mathrm{~min}$ with excess nonradioactive lysine.

JM109. A pair of transformants with leader sequences from strains 15TP and TP28 were grown in parallel overnight in minimal medium with tetracycline, then reinoculated and grown from $\mathrm{OD}_{450} 0.05$ to 0.50 . Comparisons of $\beta$-galactosidase activities were made on two such separately isolated pairs. With the first, the activity from the plasmid with the $15 \mathrm{TP}$ leader was equal to 100 ; that with the TP28 leader was then 20 . For the second pair of transformants, the activities were 90 and 20 respectively. These figures were reproducible (to within about $5 \%$ ) in at least three separate comparisons of each pair. Thus the base change in the Shine-Dalgarno sequence of strain TP28 reduces translation of $\beta$ galactosidase by $75-80 \%$.

(b) Synthesis of protein L28 by strain AM90. If protein L33 regulates translation of the $\operatorname{rpm} B, G$ operon, synthesis of protein L28 should be poorly controlled in strain AM90, which lacks protein L33. Strain AM90 labelled with $\left[{ }^{3} \mathrm{H}\right]$ lysine for two generations in TAA medium was mixed with strain A19 grown similarly with $\left[{ }^{14} \mathrm{C}\right]$ lysine. The ribosomal proteins were extracted and separated on two-dimensional gels. In four experiments, $A_{i}$ values (see Methods) for protein L28 were 0.84, 0.95, 0.98 and 1.01 . Thus protein L28 does not accumulate in strain AM90. Moreover, in pulse-labelling experiments with strain AM90 (similar to those below with strain AM108), protein L28 was synthesized at a normal rate and was then stable. The implication is that protein L33 by itself does not regulate the $\operatorname{rpmB}, G$ operon.

(c) Rates of synthesis of ribosomal proteins by strain AM108. In strain TP28 ribosomal protein synthesis is poorly balanced. At least ten proteins (S6, S12, S13, L5, L11, L14, L24, L27, L32, L34) are made at rates typically $20-30 \%$ faster than required to sustain ribosome synthesis; in all cases except protein L11, 'excess' protein is degraded (Butler \& Wild, 1984). For similar experiments with strain AM108, organisms growing exponentially in TAA medium were pulse-labelled for $2 \mathrm{~min}$ with carrier-free $\left[{ }^{3} \mathrm{H}\right]$ lysine, then chased for $2 \mathrm{~min}$ with excess non-radioactive lysine. A sample was taken and 

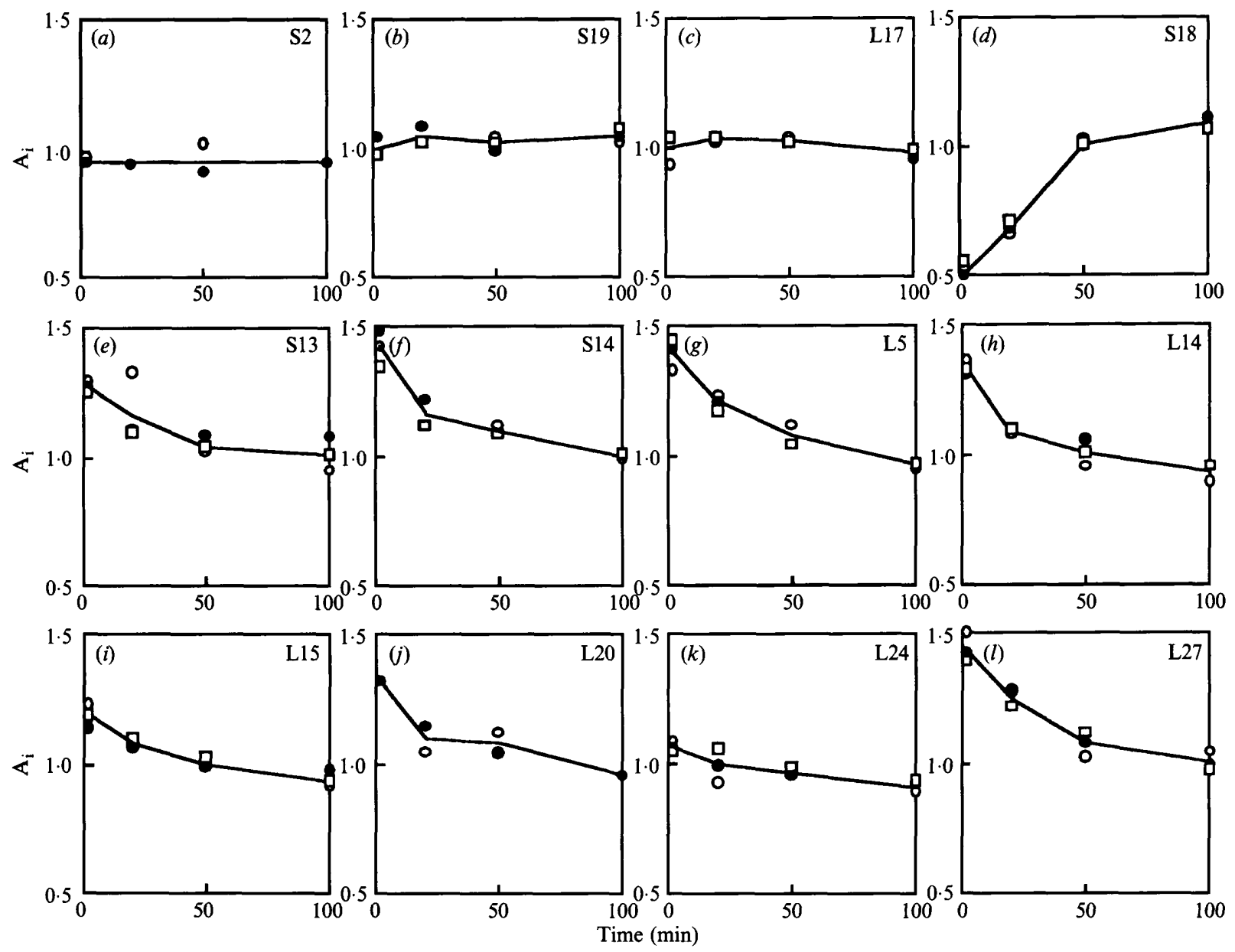

Fig. 7. Stability of ribosomal proteins in strain AM108. The panels show $A_{i}$ values after a 2 min pulse with $\left[{ }^{3} H\right] l y s i n e$ and during a subsequent chase with excess lysine. $(a, b, c)$ Proteins S2, S19, L17, representative of stable proteins; $(d)$ protein S18 (see text); $(e-l)$ the unstable proteins S13, S14, L5, L14, L15, L20, L24 and L27. The panels superimpose results of three separate experiments (O, and $\square)$.

others at 20,50 and $100 \mathrm{~min}$; each was mixed with a culture of strain AM108 labelled with $\left[{ }^{14} \mathrm{C}\right]$ lysine during growth for two generations. Proteins were extracted from the mixtures for electrophoresis. The $A_{i}$ values from the 4 min sample indicate relative rates of synthesis; values in later samples show the subsequent stability of the newly-made proteins. The measurements encompassed about 45 proteins. Those excluded were L28 and L33, missing from strain AM108, and, for technical reasons, S1, S11, L7 L12, and L34. One experiment is summarized in Fig. 6. In the pulsed sample (Fig. $6 a$ ), about a quarter of the $A_{i}$ values are outside the range 0.85-1.14. Thus strain AM108 fails to make an appreciable proportion of its ribosomal proteins at an optimum rate, although, after the chase (Fig. $6 b$ ), $A_{i}$ values are tightly clustered and reflect the ribosomal protein content of exponentially-growing organisms. The $A_{i}$ values for some individual proteins are shown in Fig. 7. The largest category is the 30 or so made at normal rates and subsequently stable; three examples are S2, S19 and L17 (Fig. 7a-c). Protein S18 is exceptional; the $A_{i}$ value increases from 0.5 to 1 during the chase (Fig. $7 d$ ), probably because $\mathrm{S} 18$ is modified by an acetylation that alters its mobility (Isono, 1980). Seven ribosomal proteins are consistently oversynthesized $\left(A_{i} 1 \cdot 20-1 \cdot 45\right)$ and their excess degraded. These are S13, S14, L5, L14, $\mathrm{L} 15, \mathrm{~L} 20$ and $\mathrm{L} 27$; L24 is a possible member of this group (Fig. 7e-l). Similar experiments (not shown) were done with strains AM and A19. Here, ribosomal protein synthesis was well balanced, with nearly all proteins made at normal rates and then stable. In both strains, the exceptions were (i) proteins $\mathrm{S} 5$ and $\mathrm{S} 18$, whose $\mathrm{A}_{\mathrm{i}}$ values increased during the chase from about 0.8 (S5) or 0.4 (S18) to 1.0 (like S18, protein S5 is acetylated: Isono, 1980), and (ii) proteins S6 and S19, which were moderately oversynthesized $\left(A_{i} 1 \cdot 1-1 \cdot 2\right)$ and somewhat unstable (in strain AM, protein L20 was also in this category, as was protein S21 of strain A19). 


\section{Discussion}

Strain TP28 grows slowly, has a high RNA content, accumulates ribosome precursor particles, shows unbalanced synthesis of ribosomal proteins and has completed ribosomes that function poorly. This complex phenotype results from a $G$ to $A$ base change in a ribosome-binding site in the leader region of the mRNA of the $\operatorname{rpmB}, G$ operon. The change reduces the number of base pairs between the Shine-Dalgarno sequence and its complement in 16S rRNA from four to three. This is perhaps sufficient to reduce translation in lac fusions by the $80 \%$ noted. However, as emphasized for example by Gold (1988), sequence changes often affect secondary and tertiary structures that can determine accessibility of ribosome-binding sites and initiation codons. The $80 \%$ reduction in fusions is greater than the $50 \%$ reduction in synthesis of proteins L28 and L33 in strain TP28 (Butler $\&$ Wild, 1984). The latter figure may be an underestimate. However, if translation of the operon is inhibited by a product, the reduced production of L28 and L33 by strain TP28 may be partially compensated by less inhibition of translation.

Strains AM90 and 108 were isolated as revertants of strain AM to erythromycin-independence (Dabbs, 1979). Strain AM90 has the element IS3 inserted into rpmG while in strain AM108, IS1 is located within rpmB. At the ends of both insertions are the repeated sequences that distinguish newly-transferred elements from resident sequences such as the IS1 copy immediately distal to the gene (rpsT) for ribosomal protein S20 (Mackie, 1986). Such sequences are polar (Jaskunas \& Nomura, 1977) so that insertion into $r p m B$ should prevent synthesis from $r p m G$. Inactivation of a ribosomal protein gene by an insertion sequence has been noted in other circumstances (e.g. Schnier \& Isono, 1984) but is not the only mechanism for suppressing erythromycin-dependence. In strain AM109, suppression results from an amber mutation in $r p l X$, coding for protein L24 (Nishi et al., 1985), while electrophoretically-altered proteins, and therefore presumably missense mutations, produce reversion of the erythromycin-dependent strain 103 to independence (Wild, 1988).

In strain TP28, rates of synthesis of proteins L28 and L33 are reduced to similar extents; internal initiation of translation of protein L33 is thus unlikely. This operon therefore provides another example of translational coupling in ribosomal protein synthesis (Nomura et al., 1984). In most ribosomal protein operons, regulation of translation is by a protein of the operon that is preferentially incorporated into assembling ribosomes but if in excess, binds to an equivalent secondary or tertiary structure in its mRNA, thereby blocking translation (Draper, 1989). If regulation of the $\operatorname{rpmB}, G$ operon conforms to this pattern, the protein is unlikely to be L33 because synthesis of protein L28 is normal in strain AM90, which fails to make L33. [In strain AM90 there may be synthesis of an N-terminal fragment of protein L33. This is unlikely to be stable; no crossreacting material was detected by Dabbs et al. (1983).]

The contrasting phenotypes of strains TP28 and AM108 are striking. The former undersynthesizes proteins L28 and L33, has a high RNA content and accumulates quantities of abnormal ribosome precursor particles. The latter synthesizes neither protein but makes ribosome virtually normally; moreover, the RNA content is no higher than that of its parent, strain AM, and about half that of strain 807 , which has the ribosome mutation of strain TP28. Ribosome assembly by strain TP 28 requires the maturation of $47 \mathrm{~S}$ particles to $50 \mathrm{~S}$ ribosomes. If the major limiting factor were the restricted availability of proteins L28 and L33, there should be a much greater delay in strain AM108. However, in strain AM108, both assembly and the assembly time are normal. It is thus likely that the kinetics of maturation of $47 \mathrm{~S}$ particles involve not only the binding of proteins L28 and L33 but also the (re)association of the other proteins (L16, L25, L27) in which 47S particles are deficient (Butler \& Wild, 1984). The substoicheiometry of protein L16 (about 0.3 of a copy per particle) may be particularly significant. The 47S particles have no peptidyltransferase activity (Butler et al., 1980); protein L16 is implicated in assembly and stabilization of the peptidyltransferase centre (Tate et al., 1987). Reconstitution intermediates that lack protein L16 show large $\mathrm{Mg}^{2+}$-dependent conformational changes (Dohme \& Nierhaus, 1976), as do 47S particles. In some strains of $E$. coli that can overexpress mutant forms of protein L2, synthesis of $50 \mathrm{~S}$ subunits is blocked at the stage of aberrant ' $48 \mathrm{~S}$ ' particles that have no protein L16 and have reduced amounts of proteins L28, L33 and L34; results do not show whether the reductions are due to the alteration in L2 or the absence of L16 (Romero et $a l ., 1990)$. In the in vitro assembly map for $E$. coli $50 \mathrm{~S}$ ribosomes (Herold \& Nierhaus, 1987), proteins L16, L25, L27, L28 and L33 cluster around protein L15. All, except protein L33, which is present in substoicheiometric amounts in $\mathrm{RI}_{50}(1)$ particles, are in the second group of proteins to bind during assembly in vitro. Structural relationships between this group of proteins may help explain some of the features of ribosome assembly in strain TP28. However, it is still puzzling why these are not reflected in strain AM108.

Regulation of ribosomal protein synthesis is no more impaired in strain AM108 than in TP28. Strain TP28 oversynthesizes proteins S6, S12, S13, L5, L11, L14, L27, L32 and L34 (Butler \& Wild, 1984); strain AM108 makes an excess of, and then degrades, S13, S14, L5, 
L14, L15, L20, L24 and L27. The catalogues overlap and together comprise the first four products of the long $s p c$ operon (proteins L14, L24, L5 and S14) plus other proteins whose genes are promoter-proximal in their operons. (The exception is protein L15, whose gene is distal in the $s p c$ operon.) One explanation (Butler \& Wild, 1984) for unbalanced synthesis in strain TP28 was that stresses in one regulatory circuit $(\operatorname{rpmB}, G)$ were reflected in other operons. In this case, failure of strain AM108 to make the two proteins should, but does not, have more dramatic consequences. Another, now more likely explanation that can be tested, is that the ribosomes of both strains translate with difficulty and are prone to detach prematurely from mRNA. This polarity might lead to oversynthesis of proteins whose genes are promoter proximal.

It is also not clear why strain TP28 accumulates much more RNA than strain AM108. A contrasting situation is that with strains $\mathrm{R} 1$ and $\mathrm{R} 8$, two revertants to independence of the erythromycin-dependent strain, 103: the strain (R8) that lacks a protein (L19) has a high RNA content; the content is normal in the strain (R1) with an L19 of altered mobility (Wild, 1988). It is difficult to explain these, and other, examples as regulation by ribosomal proteins that are altered or absent. A more promising explanation is that accumulation of RNA results from failure of growth rate control by completed ribosomes. The proposal (Jinks-Robertson et al., 1983) that rRNA synthesis is inhibited by free, nonfunctioning ribosomes has been modified by the suggestion that ribosome production is monitored at initiation (or perhaps subsequent steps) of protein synthesis (Cole $e t$ al., 1987; Yamagishi et al., 1987). On this basis, the ribosomes of strain AM108 lack two proteins but retain their signalling capacity, whereas ribosomes of strain TP28, with a complete set of proteins but perhaps conformationally altered, are unable to signal properly. Clarification may come by comparing the ability of these ribosomes to function in the stages of protein synthesis. An alternative is to examine RNA synthesis by strains with established defects in protein synthesis such as the mutant lacking protein S20 that is defective in translation initiation (Gotz et al., 1990).

The early stages of this work benefited greatly from discussions with Dr Peter Butler, who died in 1991. We salute his memory and his courage.

\section{References}

BUTLER, P. D. \& WILD, D. G. (1984). Ribosomal protein synthesis by a mutant of Escherichia coli. European Journal of Biochemistry 144, 649-654.

Butler, P. D. \& WiLD, D. G. (1985). The location of a mutation affecting ribosomal protein synthesis by Escherichia coli. Journal of General Microbiology 131, 135-144.
Butler, P. D., Sims, P. F. G. \& Wild, D. G. (1979). Abnormal ribosome assembly by a mutant of Escherichia coli. Biochemical Journal 182, 493-502.

Butler, P. D., Sims, P. F. G. \& WiLD, D. G. (1980). Intermediates in the assembly of ribosomes by a mutant of Escherichia coli. Biochemical Journal 190, 157-170.

Cole, J. R., Olsson, C. L., Hershey, J. W. B., Grunberg-Monago, M. \& Nomura, M. (1987). Feedback regulation of rRNA synthesis in Escherichia coli: requirement for initiation factor IF2. Journal of Molecular Biology 198, 383-392.

DABBS, E. R. (1979). Selection for Escherichia coli mutants with proteins missing from the ribosome. Journal of Bacteriology 140, $734-737$.

Dabbs, E. R., HaSenbank, R., Kastner, B., RaK, K.-H., Wartusch, B. \& STOFFLER, G. (1983). Immunological studies of Escherichia coli mutants lacking one or two ribosomal proteins. Molecular and General Genetics 192, 301-308.

DENNIS, P. P. (1974). In vivo stability, maturation and relative differential synthesis rates of individual ribosomal proteins in Escherichia coli B/r. Journal of Molecular Biology 88, 25-41.

Dohme, F. \& Nierhaus, K. H. (1976). Total reconstitution and assembly of 50S subunits from Escherichia coli ribosomes in vitro. Journal of Molecular Biology 107, 585-599.

DRAPER, D. E. (1989). How do proteins recognize specific RNA sites? New clues from autogenously regulated ribosomal proteins. Trends in Biochemical Sciences 14, 335-338.

GESTELAND, R. F. (1966). Isolation and characterization of ribonuclease I mutants of Escherichia coli. Journal of Molecular Biology 16, 67-84.

GoLD, L. (1986). Posttranscriptional regulatory mechanisms in Escherichia coli. Annual Review of Biochemistry 57, 199-233.

Gotz, F., DabBs, E. R. \& GualerzI, C. O. (1990). Escherichia coli $30 S$ mutants lacking protein S20 are defective in translation initiation. Biochimica et Biophysica Acta 1050, 93-97.

HeRold, M. \& NiERHAUs, K. H. (1987). Incorporation of six additional proteins to complete the assembly map of the 50S subunit from Escherichia coli ribosomes. Journal of Biological Chemistry 262, 8826-8833.

IsONO, K. (1980). Genetics of ribosomal proteins and their modifying and processing enzymes in Escherichia coli. In Ribosomes: Structure, Function \& Genetics, pp. 641-669. Edited by G. Chambliss, G. R. Craven, J. Davies, K. Davis, L. Kahan \& M. Nomura. Baltimore: University Park Press.

JASKUNAS, S. R. \& NomURA, M. (1977). Organization of ribosomal protein genes of Escherichia coli as analysed by polar insertion mutations. Journal of Biological Chemistry 252, 7337-7343.

Jinks-Rober tSON, S., GourSe, R. L. \& Nomura, M. (1983). Expression of rRNA and tRNA genes in Escherichia coli: evidence for feedback regulation by products of rRNA operons. Cell 33, 865-876.

LeE, J. S., AN, G., Friesen, J. J. \& Isono, K. (1981). Cloning and nucleotide sequence of the genes for Escherichia coli ribosomal proteins L28 (rpmB) and L33 (rpmG). Molecular and General Genetics 184, 218-223.

LINDAHL, L. (1975). Intermediates and time kinetics of the in vivo assembly of Escherichia coli ribosomes. Journal of Molecular Biology 92, 15-37.

LINDAHL, L. \& ZENGEL, J. M. (1986). Ribosomal genes in Escherichia coli. Annual Review of Genetics 20, 297-326.

MACKIE, G. A. (1986). Structure of the DNA distal to the gene for ribosomal protein S20 in Escherichia coli K12: presence of a strong terminator and an IS1 element. Nucleic Acids Research 14, 6965-6981.

Maguire, B. A., Deaves, J. K. \& Wild, D. G. (1989). Some properties of two erythromycin-dependent strains of Escherichia coli. Journal of General Microbiology 135, 575-581.

MARKEY, F. \& WILD, D. G. (1975). A 30S precursor of 30S ribosomes in a mutant of Escherichia coli. Biochemical Journal 151, 463-465.

Michaels, G. A. (1972). Ribosome maturation in Escherichia coli growing at different growth rates. Journal of Bacteriology 110, 889-894.

Miller, J. H. (1972). Experiments in Molecular Genetics. Cold Spring Harbor, NY: Cold Spring Harbor Laboratory. 
Nishi, K., DABbs, E. R. \& SChNIER, J. (1985). DNA sequence and complementation analysis of a mutation in the $r p l X$ gene from Escherichia coli leading to loss of ribosomal protein L24. Journal of Bacteriology 163, 809-894.

Nomura, M., Gourse, R. \& Baughman, G. (1984). Regulation of the synthesis of ribosomes and ribosomal components. Annual Review of Biochemistry 53, 75-117.

Romero, D. P., Arredondo, J. A. \& Traut, R. R. (1990). Identification of a region of Escherichia coli ribosomal protein L2 required for assembly of L16 into the 50S ribosomal subunit. Journal of Biological Chemistry 265, 18185-18191.

Ross, W., Thompson, J. F., Newlands, J. T. \& Gourse, R. L. (1990). $E$. coli Fis protein activates ribosomal RNA transcription in vitro and in vivo. EMBO Journal 9, 3733-3742.

Sambrook, J., Fritsch, E. F. \& Maniatis, T. (1989). Molecular Cloning: a Laboratory Manual, 2nd edn. Cold Spring Harbor, NY: Cold Spring Harbor Laboratory.

SCHNIER, J. \& IsONO, K. (1984). Insertion of IS1 into the $r p s E$ gene for ribosomal protein $\mathrm{S} 5$ confers cold sensitivity in Escherichia coli. Molecular and General Genetics 195, 364-366.
Sims, P. F. G. \& WiLD, D. G. (1976). Peptidyl transferase activity of ribosomes and a ribosome precursor from a mutant of Escherichia coli. Biochemical Journal 160, 721-726.

Tate, W. E., Sumpter, V. G., Trotman, C. N. A., Herold, M. \& NiERHAUS, K. H. (1987). The peptidyl transferase centre of the Escherichia coli ribosome. The histidine of protein L16 affects the reconstitution of the active centre but is not essential for releasefactor mediated peptidyl-tRNA hydrolysis and peptide bond formation. European Journal of Biochemistry 165, 403-408.

Ulbrich, B. \& Nierhaus, K. H. (1975). Pools of ribosomal proteins in Escherichia coli: studies on the exchange of proteins between pools and ribosomes. European Journal of Biochemistry 57, 49-54.

WILD, D. G. (1988). Reversion from erythromycin dependence in Escherichia coli: strains altered in ribosomal sub-unit association and ribosome assembly. Journal of General Microbiology 134, $1251-1263$

YAMAGishi, M., DE Boer, H. A. \& Nomura, M. (1987). Feedback regulation of $r R N A$ synthesis: a mutational alteration in the antiShine-Dalgarno region of the 16S rRNA gene abolishes regulation. Journal of Molecular Biology 198, 547-550. 